\title{
CARBAMOYL MYCOPHENOLIC ACID ETHYLESTER, AN ORAL ANTITUMOR AGENT
}

\author{
Seikichi Suzuki and TAKashi Mori \\ Research Laboratories, Chugai Pharmaceutical Co., Ltd. \\ Toshima-ku, Tokyo, Japan
}

(Received for publication September 27, 1975)

\begin{abstract}
Several derivatives of mycophenolic acid (MA) were tested for their antitumor activity against leukemia L-1210 when administered orally and carbamoyl mycophenolic acid ethylester (CMAE) was selected as the most active antitumor agent in these tests. An oral administration of CMAE also inhibited the growth of EHrLICH solid carcinoma, NF sarcoma, myeloma X-5563 and sarcoma 180 in mice. In comparison with antitumor activity of MA, the improvement in activity of CMAE against leukemia L-1210 and EhrLich solid carcinoma was indeed remarkable. CMAE seems to be less immunosuppressive than MA.
\end{abstract}

As reported by several workers, ${ }^{2,3,4)}$ mycophenolic acid (MA) is effective by oral administration as well as by parenteral administration. We previously reported that some derivatives of MA possess higher suppressive effect on leukemia L-1210 (L-1210) than the parent compound on intraperitoneal administration. ${ }^{1)}$ In this paper, we will describe the process of selection of an orally active antitumor agent, carbamoyl mycophenolic acid ethylester with antitumor activity against several experimental tumors in mice.

\section{Materials and Method}

Agents. MA and its derivatives were purified or synthesized and supplied by the Department of Synthetic Organic Chemistry of our Institute. 5-Fluorouracil (5FU), 6-mercaptopurine (6MP) and cyclophosphamide (CPA) were obtained commercially. These agents were dissolved in saline or suspended in $0.25 \%$ carboxymethylcellulose-saline and they were administered orally $(0.2 \mathrm{ml} /$ mouse).

Evaluation of antitumor activity. Unless otherwise stated agents were administered orally once daily for 5 days starting 18 hours after inoculation of tumors.

Test systems with L-1210, EHrLICH solid carcinoma (ESC) and X-5563 plasma cell myeloma $(\mathrm{X}-5563)$ and evaluation of activities in these systems were described in the preceding paper. ${ }^{1)}$

Minced NF sarcoma (NFS) $(10 \mathrm{mg} /$ mouse) was transplanted subcutaneously to $d d y / S$ mice ( 4 week-old, male). Sarcoma 180 ascites tumor cells $\left(5 \times 10^{6}\right.$ cells/mouse) were inoculated by the same route into the same strain of mice. Antitumor activity was evaluated by the tumor weight ratios (treated/control $\times 100$ ) on the 10 th day after tumor inoculation both in the NF sarcoma and in the sarcoma 180 solid tumor (S-180).

In the L-1210 system, optimal dose (OD) was obtained from MaxILS (maximum increase in life span). $\operatorname{ILS}_{30}(30 \%$ increase life span dose) was obtained graphically. Chemotherapeutic ratio $(\mathrm{CR})$ was calculated by the formula: $\mathrm{CR}=\mathrm{OD} / \mathrm{ILS}_{30}$.

Acute toxicity of agent was calculated by a single oral administration to $d d y / S$ mice, and from the number of survivors on the 10th day after the injection (method of LiTchFieldWilcoxon). $\quad \mathrm{LD}_{10}$ with 5 daily consecutive oral administrations was also obtained and used as the maximum tolerable dose (MTD) for the evaluation of antitumor activities of agents. 
In the 4 solid tumor systems, $\mathrm{ED}_{80}(90 \%$ inhibitory dose) was obtained graphically, and then the chemotherapeutic indices (CI) were calculated by the formula: $\mathrm{CI}=\mathrm{ED}_{80} / \mathrm{MTD}$.

\section{Results}

1. Effect of Orally Administered MA Derivatives against L-1210.

Ten MA derivatives, which are active when given intraperitoneally against L-1210, were tested for anti L-1210 activity when administered orally (Table 1).

The MaxILS of all tested compounds were above 1.30 and for 6 out of 10 compounds they were above 1.60. The highest CR value, 3.4, was obtained with III. The highest MaxILS value was observed with VII. Compound I, which has relatively high CR and MaxILS values was selected for further investigation.

\section{Antitumor activity of CMAE}

Activity against Several Tumors.

CMAE was evaluated against 4 tumors (Tables 2, 3, 4 and 5). $\mathrm{ED}_{90}$ 's against ESC, NFS, X-5563 and S-180 were $105,500,290$ and $180 \mathrm{mg} / \mathrm{kg}$, respectively. ESC was most sensitive to CMAE whereas NFS was least susceptible to CMAE.

Activities of various dosage levels against L-1210 are shown in Table 6. In the group treated with $900 \mathrm{mg} / \mathrm{kg}$ of CMAE, mice died due to toxicity of the agent. MaxILS (T/C in Table 6) was obtained with $500 \mathrm{mg} / \mathrm{kg}$ dose. There was no detectable activity at the $50 \mathrm{mg} / \mathrm{kg}$

Table 1. Antitumor activities of orally administered MA derivatives against leukemia L-1210 in mice

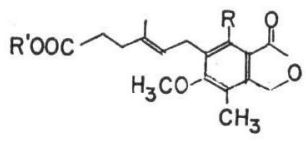

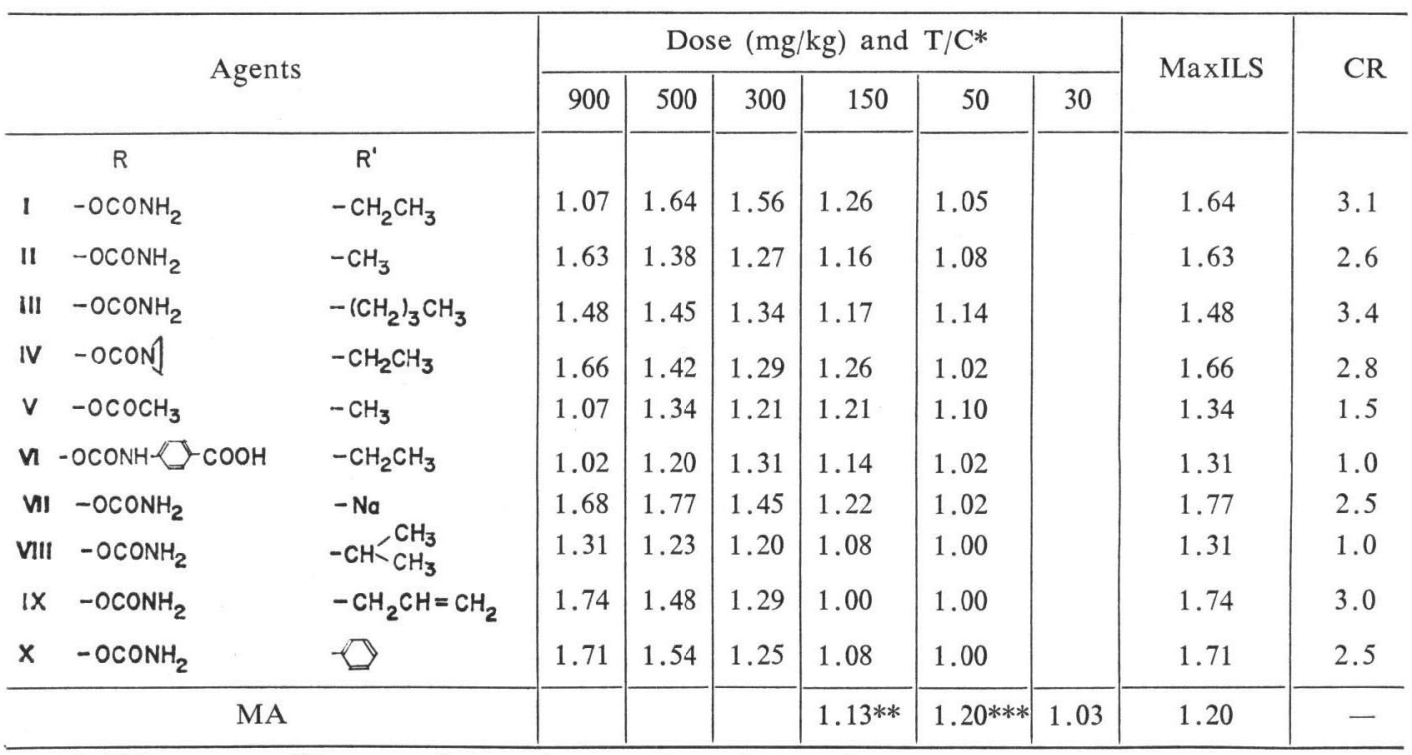

* $\mathrm{T} / \mathrm{C}$, average life-span of treated group/that of control group.

** $100 \mathrm{mg} / \mathrm{kg}$, *** $70 \mathrm{mg} / \mathrm{kg}$ 
Table 2. Antitumor activity of orally administered CMAE against EHRLICH solid carcinoma in mice

\begin{tabular}{c|c|c|c}
\hline $\begin{array}{c}\text { Dose* } \\
(\mathrm{mg} / \mathrm{kg})\end{array}$ & $\begin{array}{c}\text { Av. tumor wt. } \\
(\mathrm{mg})\end{array}$ & $\mathrm{T} / \mathrm{C}(\%)$ & Death/total \\
\cline { 2 - 3 } \cline { 2 - 3 } 900 & 0 & 0 & $4 / 10$ \\
500 & 3.7 & 0.5 & $2 / 10$ \\
300 & 58.8 & 8.2 & $0 / 10$ \\
150 & 92.2 & 13.0 & $0 / 10$ \\
50 & 135.4 & 19.1 & $0 / 10$ \\
30 & 249.6 & 35.2 & $0 / 10$ \\
Control & 709.2 & 100 & $0 / 10$ \\
\hline
\end{tabular}

* Dosage once daily for 5 days

Table 3. Antitumor activity of orally administered CMAE against sarcoma NF in mice

\begin{tabular}{c|c|c|c}
\hline $\begin{array}{c}\text { Dose* } \\
(\mathrm{mg} / \mathrm{kg})\end{array}$ & $\begin{array}{c}\text { Av. tumor wt. } \\
(\mathrm{mg})\end{array}$ & $\mathrm{T} / \mathrm{C}(\%)$ & Death/total \\
\cline { 1 - 2 } 500 & 5.4 & 0.2 & $2 / 10$ \\
300 & 108.5 & 5.0 & $0 / 10$ \\
200 & 574.2 & 26.4 & $0 / 10$ \\
100 & 1795.4 & 82.6 & $0 / 10$ \\
50 & 2358.6 & 108.6 & $0 / 10$ \\
30 & 2359.0 & 108.6 & $0 / 10$ \\
control & 2171.4 & 100 & $0 / 10$ \\
\hline
\end{tabular}

* Dosage once daily for 5 days

Table 4. Antitumor activity of orally administered CMAE against myeloma X-5563 in mice

\begin{tabular}{c|c|c|c}
\hline $\begin{array}{c}\text { Dose* } \\
(\mathrm{mg} / \mathrm{kg})\end{array}$ & $\begin{array}{c}\text { Av. tumor wt. } \\
(\mathrm{mg})\end{array}$ & T/C (\%) & Death/total \\
\cline { 1 - 2 } 400 & 67.8 & 4.7 & $0 / 10$ \\
240 & 341.4 & 24.0 & $0 / 10$ \\
80 & 647.2 & 45.5 & $0 / 10$ \\
24 & 1405.8 & 99.0 & $0 / 10$ \\
8 & 1247.6 & 87.8 & $0 / 10$ \\
control & 1420.0 & 100 & $0 / 10$ \\
\hline
\end{tabular}

* Dosage once daily for 5 days

Table 5. Antitumor activity of orally administered CMAE against sarcoma 180 in mice

\begin{tabular}{c|c|c|c}
\hline $\begin{array}{c}\text { Dose* } \\
(\mathrm{mg} / \mathrm{kg})\end{array}$ & $\begin{array}{c}\text { Av. tumor wt. } \\
(\mathrm{mg})\end{array}$ & $\mathrm{T} / \mathrm{C}(\%)$ & Death/total \\
\cline { 2 - 3 } 500 & 10.0 & 1.2 & $1 / 10$ \\
300 & 73.2 & 7.7 & $0 / 10$ \\
100 & 370.2 & 38.9 & $0 / 10$ \\
30 & 542.0 & 57.0 & $0 / 10$ \\
10 & 649.6 & 68.3 & $0 / 10$ \\
control & 950.6 & 100 & $0 / 10$ \\
\hline
\end{tabular}

* Dosage once daily for 5 days
Table 6. Antitumor activity of orally administered CMAE against leukemia L-1210 in mice

\begin{tabular}{c|r|c}
\hline $\begin{array}{c}\text { Dose* } \\
(\mathrm{mg} / \mathrm{kg})\end{array}$ & Av. survival day & $\mathrm{T} / \mathrm{C}^{* *}$ \\
\cline { 2 - 3 } 900 & 8.0 & 1.07 \\
500 & 12.2 & 1.64 \\
300 & 11.6 & 1.56 \\
150 & 9.4 & 1.26 \\
50 & 7.8 & 1.05 \\
Control & 7.4 & 1.00 \\
\hline
\end{tabular}

* Dosage once daily for 5 days

** $\mathrm{T} / \mathrm{C}$, average life-span of treated group/that of control group.

Table 7. Activity of CMAE on leukemia L-1210 by various time schedules of oral administration

\begin{tabular}{c|r|r|r|l}
\hline $\begin{array}{c}\text { Day of } \\
\text { administration* }\end{array}$ & $\begin{array}{c}\text { MaxILS } \\
(\mathrm{T} / \mathrm{C})\end{array}$ & $\begin{array}{c}\mathrm{CR} \\
(\mathrm{mg} / \mathrm{kg})\end{array}$ & $\begin{array}{c}\mathrm{ILS}_{30} \\
(\mathrm{mg} / \mathrm{kg})\end{array}$ & $\mathrm{CR}$ \\
\cline { 1 - 3 } $1 \sim 5$ & 1.64 & 500 & 161 & 3.1 \\
$1,3,5$ & 1.80 & 700 & 115 & 6.1 \\
$1,5,9$ & 1.91 & 900 & 411 & 2.2 \\
$1 \sim 9$ & 1.81 & 300 & 83 & 3.6 \\
1 & 1.54 & 2,000 & 862 & 2.3 \\
1,5 & 1.95 & 2,000 & 597 & 3.3 \\
\hline
\end{tabular}

* After tumor inoculation

Table 8. Antitumor activity of CMAE on leukemia L-1210 by intraperitoneal administration

\begin{tabular}{c|c|c}
\hline $\begin{array}{c}\text { Dose* } \\
(\mathrm{mg} / \mathrm{kg})\end{array}$ & Av. survival day & $\mathrm{T} / \mathrm{C}^{* *}$ \\
\hline 500 & 5.4 & 0.77 \\
300 & 10.6 & 1.51 \\
150 & 12.0 & 1.72 \\
50 & 10.6 & 1.51 \\
15 & 9.0 & 1.28 \\
Control & 7.0 & 1.00 \\
\hline
\end{tabular}

* Dosage once daily for 5 days

** $\mathrm{T} / \mathrm{C}$, average life-span of treated group/that of control group.

dosage.

Therapy Schedule.

L-1210 inoculated mice were treated orally at various time schedules. From the resulting $\mathrm{T} / \mathrm{C}$ values, chemotherapeutic indices of each schedule were calculated (Table 7),

Of these 7 schedules, the 1- and 5-day dosage schedule resulted in the highest MaxILS, although OD value of this schedule was as 
Table 9. Acute toxicity of CMAE in mice

\begin{tabular}{c|c}
\hline $\begin{array}{c}\text { Dose* } \\
(\mathrm{mg} / \mathrm{kg})\end{array}$ & Death/total** \\
\hline 3,500 & $8 / 10$ \\
2,800 & $2 / 10$ \\
2,000 & $0 / 10$ \\
1,000 & $0 / 10$ \\
\hline
\end{tabular}

$\mathrm{LD}_{\mathrm{5} 0}(\mathrm{po})=3,080 \mathrm{mg} / \mathrm{kg}$

* Single oral dose

** Mice were observed for 10 days after administration.
Table 10. Mortality of mice given consecutive daily oral doses of CMAE

\begin{tabular}{c|c}
\hline $\begin{array}{c}\text { Daily dose } \\
(\mathrm{mg} / \mathrm{kg})\end{array}$ & Death/total* \\
\hline 800 & $4 / 10$ \\
600 & $3 / 10$ \\
500 & $2 / 10$ \\
300 & $1 / 20$ \\
100 & $0 / 20$ \\
\hline
\end{tabular}

* Mice were observed for 10 days after administration.

high as at $2,000 \mathrm{mg} / \mathrm{kg}$. On the other hand, the 1-, 3- and 5-days schedule resulted in the best CR value.

Route of Administration.

The activity of CMAE against L-1210 by intraperitoneal administration is presented in Table 8. These results are in agreement with those earlier results reported previously ${ }^{1)}$ and they are higher than those obtained with oral administration.

Toxicity.

Acute toxicity tests were carried out in mice (Tables 9 and 10 ). The $\mathrm{LD}_{50}$ by single oral administration and the $\mathrm{LD}_{10}$ by 5 consecutive daily oral administrations were 3,080 and 360 $\mathrm{mg} / \mathrm{kg}$, respectively: the corresponding values for MA are 2,500 and $220 \mathrm{mg} / \mathrm{kg}$. CMAE is apparently less toxic than MA.

Table 11. Effects of CMAE, MA and 6MP on the growth of COK tumor transplanted in allogenic mice

\begin{tabular}{|c|c|c|c|c|c|}
\hline Agent & $\begin{array}{l}\text { Dose* } \\
\text { (mg) }\end{array}$ & $\begin{array}{l}\text { Tumor take** } \\
\text { pos./total }\end{array}$ & $\begin{array}{l}\text { Av. tumor wt./ } \\
\text { positive animal } \\
\quad(\mathrm{mg})\end{array}$ & $\begin{array}{l}\text { Av. tumor wt.***/ } \\
\text { group } \\
(\mathrm{mg})\end{array}$ & $\mathrm{T} / \mathrm{C}(\%)$ \\
\hline CMAE & $\begin{array}{r}300 \\
100 \\
30 \\
10\end{array}$ & $\begin{array}{l}0 / 10 \\
2 / 10 \\
2 / 10 \\
3 / 10\end{array}$ & $\begin{array}{c}0 \\
592.1 \\
439.6 \\
514.0\end{array}$ & $\begin{array}{c}0 \\
118.4 \\
122.2 \\
248.0\end{array}$ & $\begin{array}{c}0 \\
32.4 \\
33.5 \\
68.0\end{array}$ \\
\hline MA & $\begin{array}{r}300 \\
100 \\
50\end{array}$ & $\begin{array}{c}- \\
4 / 10 \\
8 / 10\end{array}$ & $\begin{array}{c}- \\
115.9 \\
813.6\end{array}$ & $\begin{array}{c}- \\
48.0 \\
650.6\end{array}$ & $\begin{array}{c}- \\
13.1 \\
178.4\end{array}$ \\
\hline $6 \mathrm{MP}$ & $\begin{array}{r}80 \\
50 \\
30 \\
10 \\
3\end{array}$ & $\begin{array}{l}8 / 10 \\
8 / 10 \\
8 / 10 \\
4 / 10 \\
2 / 10\end{array}$ & $\begin{array}{r}1,031.7 \\
1,208.4 \\
1,067.5 \\
185,9 \\
478.0\end{array}$ & $\begin{array}{r}842.6 \\
968.4 \\
853.6 \\
88.0 \\
113.6\end{array}$ & $\begin{array}{r}231.1 \\
265.6 \\
234.2 \\
24.1 \\
34.1\end{array}$ \\
\hline Control & & $10 / 32$ & $1,082.3$ & 364.5 & 100 \\
\hline
\end{tabular}

Minced COK tumor ( $10 \mathrm{mg} /$ mouse) were transplanted subcutaneously to allogenic mice $(d d y / S)$. Agents were administered orally once daily for 5 days starting 18 hours after inoculation. Tenth day after tumor inoculation, tumors were weighed.

* Daily dose ** Mice which exhibited tumor weight over $100 \mathrm{mg}$ were judged as positive and those below it as negative. $* * *$ This includes weights of tumors in animals not considered positive. 


\section{Effect of CMAE on COK Tumor Transplanted in Allogenic Mice}

COK tumor originally arose from a spontaneous mammary carcinoma in a IVCS mouse. It has been maintained in our Institute in IVCS mice with a distinct strain specificity in tumor acceptability. It grows rapidly and uniformly in IVCS mice. When tumor was transplanted into $d d y / S$ mice, growth of the tumor was markedly suppressed in about $70 \%$ of the mice due to an immunological effect of the host animals. 6MP given orally enhanced the growth rate of the COK tumor in $d d y / S$ mice. Thus, this tumor-host system can be used as a screening tool for estimating immunosuppressive activity of antitumor agents.

Effects of CMAE, 6MP and MA on the growth of $\mathrm{COK}$ tumor in $d d y / S$ mice are presented in Table 11. In the mice given 80,50 and $30 \mathrm{mg} / \mathrm{kg}$ of $6 \mathrm{MP}$, a higher tumor take was observed as compared with non-treated mice. Enhancement of tumor growth was also observed in mice treated with $50 \mathrm{mg} / \mathrm{kg}$ of MA. In CMAE treated mice, neither enhancement of tumor growth nor of tumor

Table 12. Comparative antitumor activities of CMAE and other agents against leukemia L1210 in mice*

\begin{tabular}{l|c|r|r|l}
\hline Agents & $\begin{array}{c}\text { MaxILS } \\
(\mathrm{T} / \mathrm{C})\end{array}$ & $\begin{array}{c}\text { OD } \\
(\mathrm{mg} / \mathrm{kg})\end{array}$ & $\begin{array}{c}\mathrm{ILS}_{30} \\
(\mathrm{mg} / \mathrm{kg})\end{array}$ & \multicolumn{1}{c}{$\mathrm{CR}$} \\
\cline { 5 - 6 } CMAE & 1.64 & 500 & 161 & 3.1 \\
5FU & 1.43 & 30 & 19 & 1.54 \\
6MP & 1.49 & 70 & 38 & 1.84 \\
CPA & 2.02 & 100 & 36 & 2.78 \\
MA & 1.20 & 70 & - & - \\
\hline
\end{tabular}

* Oral administration

Table 13. Comparative antitumor activity* of CMAE and other agents against several solid tumors

\begin{tabular}{|c|c|c|c|c|c|}
\hline \multirow{2}{*}{ Agent } & \multirow{2}{*}{$\begin{array}{c}\mathrm{LD}_{10} \\
(\mathrm{mg} / \mathrm{kg})\end{array}$} & \multicolumn{4}{|c|}{$\mathrm{ED}_{90}(\mathrm{mg} / \mathrm{kg})$} \\
\hline & & ESC & NFS & X5563 & $\mathrm{S} 180$ \\
\hline CMAE & 360 & 105 & 500 & 290 & 260 \\
\hline $5 \mathrm{FU}$ & 54 & $>70$ & $>70$ & 36 & $\mathrm{nt} * *$ \\
\hline $6 \mathrm{MP}$ & 120 & $>120$ & 28 & 68 & 180 \\
\hline CPA & 91 & 50 & 25 & $<3$ & $n t * *$ \\
\hline MA & 220 & 118 & 260 & 155 & $n t * *$ \\
\hline
\end{tabular}

* 5 daily consecutive oral doses

** Not tested

take was observed.

4. Comparison of Antitumor Activity of CMAE and Other Antitumor Agents.

Antitumor activities of CMAE, MA and 3 other antitumor agents were compared in mice using 4 tumor systems.

Chemotherapeutic indices of these agents in L-1210 system calculated from the results as shown in Table $12 . \mathrm{LD}_{10}$ and $\mathrm{ED}_{90}$ values of these agents in other tumor systems are summarized in Table 13 and chemotherapeutic indices in these tumor systems are indicated
Table 14. Chemotherapeutic indices of CMAE and other agents against several solid tumors in mice*

\begin{tabular}{c|r|r|r|r}
\hline \multirow{2}{*}{ Agent } & \multicolumn{3}{|c}{ Chemotherapeutic index } \\
\cline { 2 - 5 } & ESC & NFS & X-5563 & S180 \\
\cline { 2 - 5 } CMAE & 3.4 & $<1.0$ & 1.2 & 1.3 \\
$5 \mathrm{FU}$ & $<1.0$ & $<1.0$ & 1.5 & $\mathrm{nt**}$ \\
6MP & $<1.0$ & 4.2 & 1.7 & $<1.0$ \\
CPA & 1.8 & 3.6 & $>30.3$ & $\mathrm{nt**}$ \\
MA & 1.8 & ca. 1.0 & 1.4 & $\mathrm{nt**}$ \\
\hline
\end{tabular}

* Oral administration

** Not tested 
in Table 14.

The CR value of CMAE in the L-1210 system was nearly equal to that of CPA and it was higher than the values for the other agents tested. The relative effectiveness of CMAE against ESC was also outstanding.

\section{Discussion}

The antitumor activities of several orally administered MA derivatives have been demonstrated in a leukemia L-1210 in mice. The data presented here indicate that all compounds tested were more effective than MA, as evaluated by MaxILS and CR values, although OD values of these compounds appear to be higher than for MA (Table 1). CMAE had a relatively low OD value but it had better MaxILS and CR values than the other compounds. This compound was therefore, selected for further investigation.

The time schedule of drug administration in relation to the tumor inoculation was found to be influential in determining the antitumor activity of CMAE. When CMAE was administered on the 1st and 5th days after the tumor inoculation, the highest MaxILS value was obtained with a relatively low CR value. When this agent was given on the 1 st, 3 rd and 5 th days after the tumor inoculation, the highest CR value was obtained. On the other hand, administration with a 1st to 5th day schedule results in a relatively low MaxILS. It is therefore reasonable to assume that administration with moderate intervals yields best chemotherapeutic activity.

As reported previously, ${ }^{2)}$ oral, subcutaneous and intraperitoneal administrations of MA are equally effective against several tumors. In contrast, intraperitoneal administration of CMAE seems to be more effective than oral administration. This result may suggest that CMAE is absorbed more easily by intraperitoneal administration.

MA is an immunosuppressive agent. ${ }^{5)}$ This character of MA may have significance relative to the clinical use of this agent. With COK tumor transplanted in allogenic mice, CMAE showed only a suppressive effect on growth of the tumor, whereas 6MP and MA showed enhancement of the tumor growth indicating a lack of immunosuppressive activity with CMAE.

When the antitumor activity of CMAE was compared with MA, CMAE has greater activities against ESC and particularly against L-1210. Our data suggest that the antitumor spectrum of CMAE may be different from that of CPA, CMAE is more effective than CPA in the ESC system, whereas CPA is more effective against NFS and X-5563 systems. Our results suggest that CMAE may be a useful orally active antitumor agent.

$$
\text { Acknowledgement }
$$

The authors are grateful to Drs. T. Akiba and H. OGawa for their advice during these studies and in the preparation of this manuscript. We also thank Prof. Y. HAshimoto, Faculty of Pharmaceutical Science, Tohoku University, for critical reviewing of the manuscript.

\section{References}

1) Suzuki, S.; S. TAKakU \& T. Mori: Antitumor activity of derivatives of mycophenolic acid. J. Antibiotics 29: 275 285, 1976

2) Suzuki, S.; K. Kimura, K. Ando, M. Sawada \& G. Tamura: Antitumor activity of mycophenolic acid. J. Antibiotics 22: 297 302, 1969

3) Sweeney, M. J.; K. Gerzon, P. N. Harris, R. E. Halmes, G. A. Poore \& R. H. Williams: Experimental antitumor activity and preclinical toxicology of mycophenolic acid. Cancer Res. 32: $1795 \sim 1802,1972$.

4) Carter, S. B.; T. J. Franklin, D. F. Jones, B. J. Leonard, S. D. Milles, R. W. Turner \& W. B. TURNER: Mycophenolic acid: An anti-cancer compound with unusual properties. Nature 223: $848 \sim 850,1969$

5) Mirsui, A. \& S. Suzuki: Immunosuppressive effect of mycophenolic acid. J. Antibiotics 22: $358 \sim 363,1969$ 